\title{
A case report: indomethacin resistance hemicrania continua or a new entity?
}

\section{Olgu sunumu: İndometazine dirençli hemicrania continua mı yoksa yeni bir başağrısı mı?}

\author{
Özlem COŞKUN, ${ }^{1}$ " Serap ÜÇLER, ${ }^{1}$ Ruhsen ÖCAL, ${ }^{2}$ Levent Ertuğrul iNAN ${ }^{1}$
}

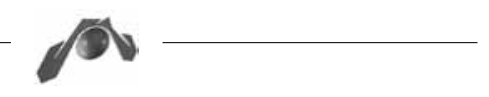

\begin{abstract}
Summary
Hemicrania continua $(\mathrm{HC})$ is a rare primary headache disorder. It presents some autonomic features (including conjunctival injection, ptosis, eyelid edema, lacrimation, nasal congestion, and rhinorrhea). Response to indomethacin treatment is the mandatory criteria for the diagnosis of HC. However, previously reported literature indicates that there are some reported cases that did not respond to indomethacin. In this case report, we present a patient who had indomethacin resistance with an associated pregabalin response. Pregabalin may be an effective treatment for hemicrania continua in some patients with indomethacin resistance.
\end{abstract}

Key words: Headache; hemicrania continua; indomethacin; pregabalin; resistance; treatment.

\begin{abstract}
Özet
Hemicrania continua (HC) nadir primer başağrısıdır. Bazı otonomik bulgularla birliktedir (konjunktival yaşarma, pitoz, gözkapağı ödemi, lakrimasyon, nazal konjesyon, rinore gibi). HC tanısı için indometazin tedavisine yanıt zorunlu tanı kriteridir. Bununla birlikte literatürde indometazine yanıt vermeyen olgular bildirilmiştir. Bu yazıda, indometazin yanıtı olmayan ancak pregabalin tedavisine yanıt veren bir olgu sunuldu. Pregabalin indometazine dirençli HC başağrısında bazı bastalar için etkili bir tedavi alternatifi olabilir.

Anahtar sözcükler: Başağrısı; hemicrania continua; indometazin; pregabalin; direnç; tedavi.
\end{abstract}

\section{Introduction}

Hemicrania continua (HC) is an uncommon primary headache disorder. $\mathrm{HC}$ is characterized by a continuous, moderate to severe, unilateral headache with periodic exacerbations. ${ }^{[1]} \mathrm{HC}$ has also ipsilateral cranial autonomic features (conjunctival injection, ptosis, eyelid edema, lacrimation, nasal congestion, rhinorrhea). In 2004 International Headache Society described second edition of International Classification of Headache Disorders (ICHD II). Diagnostic criteria of $\mathrm{HC}$ are shown Table $1 .^{[2]}$
Response to indomethacin treatment is the mandatory criteria for the diagnosis of HC. However, there are some reported cases who did not respond the indomethacin in the literature. ${ }^{[3,4]}$ There is still an unsolved question that there cases are really $\mathrm{HC}$ or a new entity.

In this case report we will present a $\mathrm{HC}$ patient who had a the indomethacin resistance but with pregabalin response.

\#Current affiliation: Department of Neurology, Gazi Üniversitesi Faculty of Medicine, Ankara

${ }^{1}$ Department of Neurology, Ministry of Health Ankara Training and Hospital, Ankara, Turkey;

${ }^{2}$ Department of Neurology, Çorum Health Hospital, Çorum, Turkey

\# Şimdiki kurumu: Gazi Üniversitesi Tıp Fakültesi Nöroloji Anabilim Dalı, Ankara

${ }^{1}$ Sağlık Bakanlığı Ankara Egitim ve Araştırma Hastanesi, Nöroloji Kliniği, Ankara;

${ }^{2}$ Çorum Devlet Hastanesi, Nöroloji Kliniği, Çorum

Submitted (Başvuru tarihi) 01.08.2012 Accepted after revision (Düzeltme sonrası kabul tarihi) 13.12.2012

Correspondence (İletişim): Dr. Özlem Coşkun, Gazi Üniversitesi Tıp Fakültesi Nöroloji Anabilim Dalı 3. Kat Poliklinikler Binası, Beşevler, Ankara, Turkey.

Tel: +90 - 312- 2024478 e-mail (e-posta): oecoskun@yahoo.com 
Table 1. International Headache Society Diagnostic criteria for hemicrania continua

\section{Description: persistent strictly unilateral headache responsive to indomethacin}

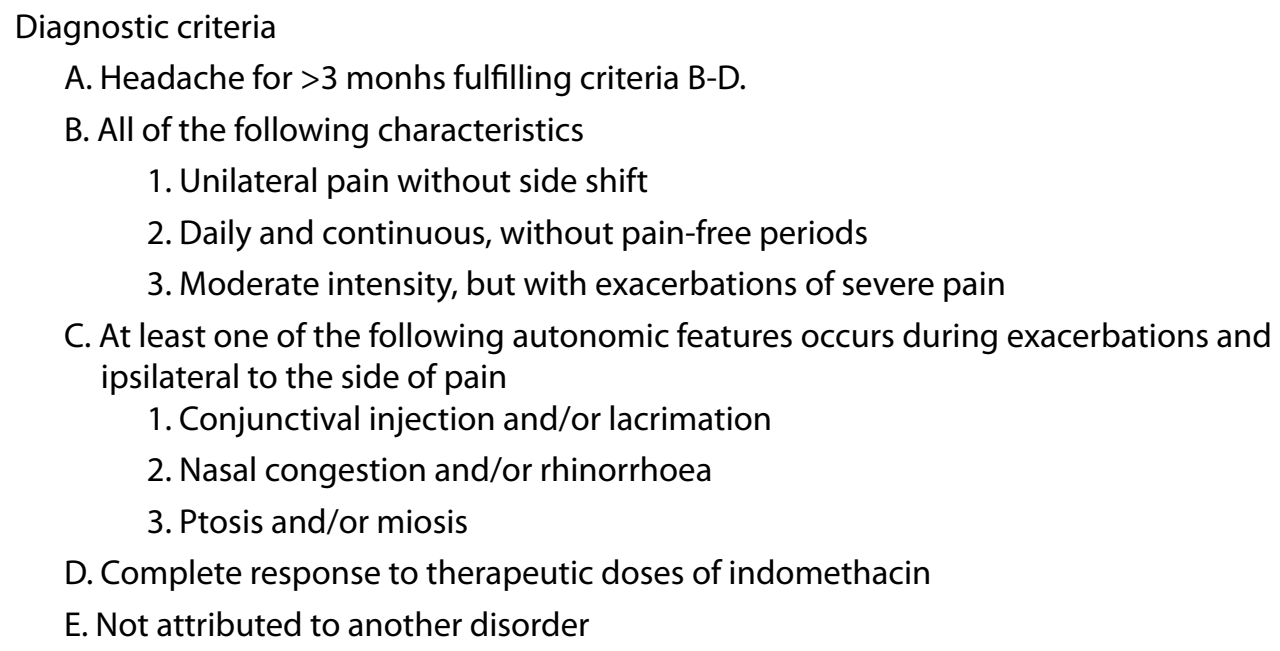

D. Complete response to therapeutic doses of indomethacin

E. Not attributed to another disorder

\section{Case Report}

A 63-year-old female presented with a twenty year history of right or left sided, temporal, periorbital headache. Pain intensity was severe and throbbing. Photophobia, phonophobia and nausea were also associated with headache. Pain duration time were about twenty hours while she did not take any analgesics. After the menopause her pain was relatively relief. About eighth months ago, she had two different types of headache. The location of the first one was left side of the head and face (orbital, maxillary, mandibular). It was severe. The duration of headache was only a few seconds. Triggers of the headaches were touch and chewing. It could be about more times a day. The localization of the second one headache was on the left temporoparietal side. Another type headache was on the same side. It was continuous. The intensity of headache was mild-moderate. One or two times a day another severe headache was accompany with continuous headache. The duration of this type headache was about tree or four hours. There was eyelid edema, many thousand of times itching sensuous of the left side of face, flushing and nausea were also associated with this type headache.

She had hypertension and diabetes mellitus. There was no other pathology. Examination of the neurological condition was normal. Cranial magnetic resonance imaging (MRI) was also normal. Her cranial computerize venography evolution was normal.
We decided to her first headache was migraine without aura, second type headache was trigeminal neuralgia and the third one was hemicrania continua? Firstly we performed indomethacin $2 \times 25 \mathrm{mg} /$ day. Treatment with indomethacin headache did not relieve so that we decided increase the dose of drug. Subsequently, the dose of indomethacin gradually increased $300 \mathrm{mg} /$ day. However, we did not any affect off pain and than indomethacin was stopped. She was started on pregabalin with slow titration to $150 \mathrm{mg}$ bid, with complete benefit after 5 days. There were two different situation this condition one of them pain had spontaneous remission or pregabalin effected. We reduced pregabaline dose and her pain reappeared. We thought that pregabalin was effective for her headache.

\section{Discussion}

The clinical features and indomethacin responsiveness of $\mathrm{HC}$ were described by Mediana and Diamond. ${ }^{[3]}$ The name of the "Hemicrania Contunia" was used by Sjaastad and Spierings. ${ }^{[5]}$ According to IHS diagnostic criteria complete or persistent response therapeutic doses of indomethacin is a must. ${ }^{[2]}$ However, many authors accepted the possibility of occurrence of indomethacin resistant HC. ${ }^{[4]}$ Our patient had all of the criteria except indomethacin response. So that we though she had indomethacin resistance $\mathrm{HC}$ type headache.

Pathogenesis of $\mathrm{HC}$ is not really understanding. 
Some scientist believe that it is a subtype of migraine however the others believe it is more closely related to the trigeminal autonomic cephalalgias. ${ }^{[6]}$ The scans revealed activation of the contrlateral posterior hypothalamus and ipsilateral dorsal rostral pons, as well as activation of the ipsilateral ventrolateral midbrain, extending over the red nucleus and substantia nigra and the bilateral pontomedullary junction. ${ }^{[7]}$ These areas have been previously demonstrated to be sites of activation migraine and trigeminal autonomic cephalalgias. ${ }^{[2]}$ Migraine and HC pathophysiology is sometimes to fit snugly into. This is why we evaluated that effect of pregabalin in this patient.

Pregabalin is recommended for the treatment of partial seizures, post herpatic neuralgia, diabetic neuropathy, as well as migraine. ${ }^{[8,9]}$ Pregabalin, through binding to the alpha 2 delta subunits of hyperexcited, voltage-gated calcium channels, reduces the calcium influx at neurons terminals and subsequently reduces the synaptic release of several excitatory neurotransmitters such as glutamate, noradrenaline and substance P. Pregabalin restores the hyperexcited calcium channels to a normal state. ${ }^{[10]}$

In a recent study, ${ }^{[8]}$ pregabalin was well tolerated and could be alternative treatment for migraine patients. Migraine and HC pathogenesis may be same pathway so that some same drugs can effective for two type headaches. Pregabalin may be better preventive treatment for hemicranias contunia patients. It has also few adverse effect. ${ }^{[8]}$

Some authors accept the occurrence of the indomethacin resistant in patients HC. ${ }^{[1]}$ However, this condition is controversy. This type headache is "a new entity?" or "indomethacin responsiveness not necessary for HC?”. We thought that this is dilemma.
We thought that pregabalin is a good choice for alternative therapy in the treatment of HC. But this is just a case report so that more studies are necessary to show effectively of pregabalin in the treatment of HC.

\section{Conflict-of-interest issues regarding the author- ship or article: None declared.}

\section{Peer-rewiew: Externally peer-reviewed.}

\section{References}

1. Prakash S, Husain M, Sureka DS, Shah NP, Shah ND. Is there need to search for alternatives to indomethacin for hemicrania continua? Case reports and a review. J Neurol Sci 2009;277(1-2):187-90. CrossRef

2. Headache Classification Committee of the International Headache Society. The International Classification of Headache Disorders: 2nd edition. Cephalalgia 2004;24 Suppl 1:9160.

3. Mariano Da Silva H, Alcantara MC, Bordini CA, Speciali JG. Strictly unilateral headache reminiscent of hemicrania continua resistant to indomethacin but responsive to gabapentin. Cephalalgia 2002;22(5):409-10. CrossRef

4. Prakash S, Shah ND, Bhanvadia RJ. Hemicrania continua unresponsive or partially responsive to indomethacin: does it exist? A diagnostic and therapeutic dilemma. J Headache Pain 2009;10(1):59-63. CrossRef

5. Sjaastad O, Spierings EL. "Hemicrania continua": another headache absolutely responsive to indomethacin. Cephalalgia 1984;4(1):65-70. CrossRef

6. Spears RC. Is gabapentin an effective treatment choice for hemicrania continua? J Headache Pain 2009;10(4):271-5.

7. Matharu MS, Goadsby PJ. Functional brain imaging in hemicrania continua: implications for nosology and pathophysiology. Curr Pain Headache Rep 2005;9(4):281-8. CrossRef

8. Pizzolato R, Villani V, Prosperini L, Ciuffoli A, Sette G. Efficacy and tolerability of pregabalin as preventive treatment for migraine: a 3-month follow-up study. J Headache Pain 2011;12(5):521-5. CrossRef

9. Tassone DM, Boyce E, Guyer J, Nuzum D. Pregabalin: a novel gamma-aminobutyric acid analogue in the treatment of neuropathic pain, partial-onset seizures, and anxiety disorders. Clin Ther 2007;29(1):26-48. CrossRef

10. Ben-Menachem E. Pregabalin pharmacology and its relevance to clinical practice. Epilepsia 2004;45 Suppl 6:13-8. 